\author{
Irina Romanovskaya ${ }^{1,2}$, Victor Kuz'min ${ }^{1,2}$, Olga Oseychuk ${ }^{1}$, \\ Eugeniy Muratov ${ }^{1}$, Anatoliy Artemenko ${ }^{1}$ and Sergei Andronati ${ }^{1,2}$
}

\title{
QSPR ANALYSIS OF PEROXIDASE SUBSTRATES REACTIVITY
}

\author{
${ }^{1}$ A.V. Bogatsky Physico-Chemical Institute, NAS of Ukraine, \\ 86 Lustdorfskaya str., 65080 Odessa, Ukraine \\ 2..I. Mechnikov Odessa National University, 2 Dvoryanskaya str, 65026 Odessa, Ukraine \\ romairina@gmail.com
}

Received: N ovember 11, 2008

(c) Romanovskaya I., Kuz’min V., Oseychuk O., Muratov E., Artemenko A., Andronati S., 2009

\begin{abstract}
Quantitative structure-property relationship (QSPR) analysis of phenol derivatives reactivity in the horseradish peroxidase catalyzed oxidative reactions was carried out. The statistic models, which describe the substituted phenols reactivity $\left(K_{m}^{-1}, V_{m a x}\right)$ quite adequately, were obtained by multiple linear regression and partial least squares (PLS) methods. The electronic parameters of molecules, their lipophylicity, molecular refraction, and form parameters were used as descriptors for molecular structure. The obtained models allow to predict the reactivity of the new phenolic substrates with satisfactory reliability.
\end{abstract}

Keywords: QSPR analysis, PLS, MLR, phenolic substrates, horseradish peroxidase, computer prediction.

\section{Introduction}

One of the enzymes which are widely used in chemical enzymology, biochemical analysis, immunoanalysis, in medicinal practice, as well as in biotechnology for the removal of phenolic compounds from waste waters is the horseradish peroxidase (HRP) [1-3]. Peroxidase (E.C. 1.11.1.7) is a calcium-containing hemeglycoprotein; its prostetic group is presented by protoheme - a complex of trivalent iron with $1,3,5,8$ tetramethyl-2,4-divinylporphyn-6,7-dipropionic acid (protoporphyrin IX) (Fig. 1). The enzyme catalyses the reactions of peroxidative oxidation of substrates and is characterized by high specificity for hydrogen peroxide as a hydrogen acceptor and low specificity for substrate - hydrogen donor. Such substrates are represented by phenolic compounds, naphtols, 4-hydroxybiphenyl, hydroquinone, guaiacol, aromatic amines, etc. [4-7].

Peroxidase oxidation of phenols is a three-stage cyclic reaction. The first step is HRP-catalyzed cleavage of hydrogen peroxide with HRP I complex formation, which is a radical-cation. HRP I accepts one electron from the substrate molecule (phenol), forming HRP II, which contains one oxidative equivalent more than enzyme in native state, but is not a radical-cation. Then HRP II accepts one electron from the next substrate molecule, forming the enzyme in native state. Concerning the electron fate, its loss is usually accompanied by loss of proton, which brings to radical formation. Radicals of oxidized phenols are polymerized in final product (Scheme 1).

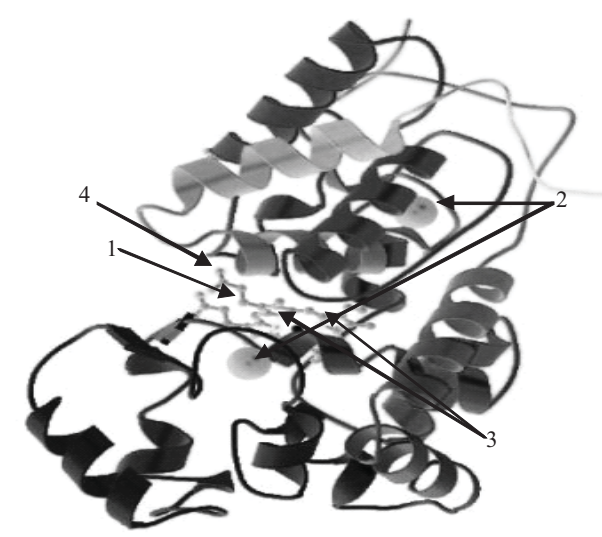

Fig. 1. HRP spatial structure: heme (1), calcium ions (2), two key amino acid residues - proximal (under the heme) and distal (over the heme) histidine residue (3), and distal arginine residue in the pocket (4)

Some publications $[8,9]$ have been devoted to the search of the relationship between the phenolic compound structure and the degree of its bioconversion at peroxidasecatalyzed oxidative reactions. For example, electronodonor substituents in the aromatic ring of substrate, unlike electronoacceptor ones, to a greater extent promote enzymatic conversion. Such effect is clued to the fact, that the higher electronodonor properties of phenol substituent, the more electron density is transferred to 
the hemine complex formed, which brings to the increasing of the enzyme activity in the processes of peripheral electron transfer in radical polymerization reactions.

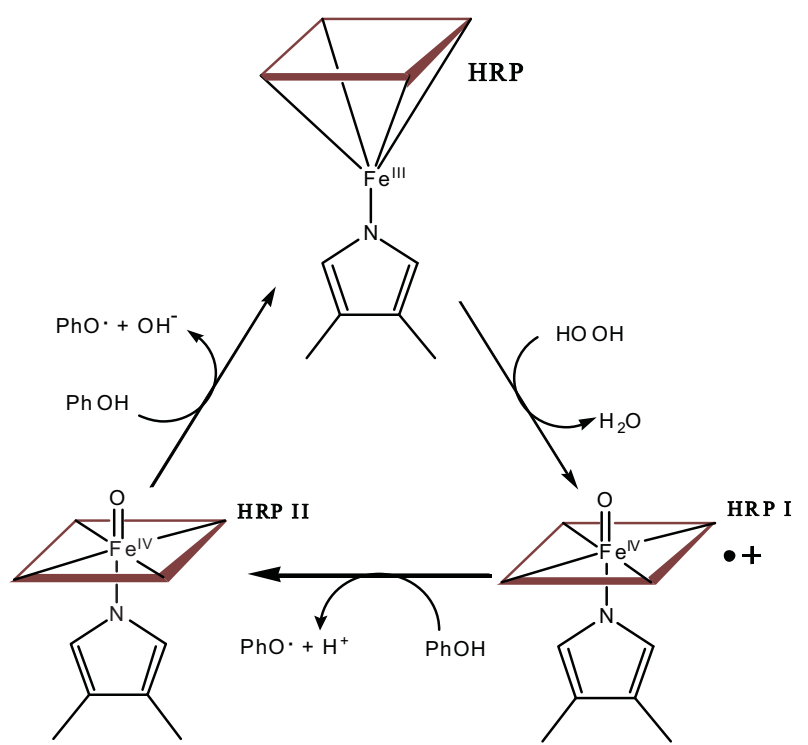

Scheme 1. Changes in horseradish peroxidase active center during the phenol oxidation process

Investigations $[10,11]$ devoted to QSPR analysis of small set of peroxidase substrates (phenol, $p$-chlorophenol, resorcinol, $m$-cresol, $p$-cresol, $p$-hydroxybenzoic acid, $p$-metoxyphenol, $p$-hydroxybenzaldehyde) are known. One-parametric linear regression, based on the estimation of highest occupied molecular orbital (HOMO) energy, enables prediction of the relative changes of total transformation rate of the compounds mentioned in these works.

The relationship between structure of phenols and their bioconversion degree has been revealed by the authors [12]. This dependence was characterized by regression equation with the highest occupied molecular orbital (HOMO) and the lowest unoccupied molecular orbital (LUMO) energies as structural descriptors. However, adequate statistical equation with the use of these parameters for such kinetic characteristics of peroxidase catalyzed oxidation of phenol derivatives oxidation reaction as its maximum rate $\left(V_{\max }\right)$ and reciprocal Michaelis constant $\left(K_{m}^{-1}\right)$ - index of phenols affinity for the enzyme, was not obtained.

Therefore, in the present work QSPR analysis of phenols reactivity $\left(V_{\max }, K_{m}^{-1}\right)$ has been carried out on the base of enlarged set of structural descriptors. These parameters describe forms of investigated molecules (moments of inertia - I.I $I_{x, y, z}$ and their ratios), their electronic structures $\left(E_{\text {HOMO }} E_{\angle U M O}\right.$, phenolic oxygene atom partial charge $q_{O}$, total atoms electronegativity $E N$, dipole moment $\mu$ ), molecular refraction $R f$, and lipophilicity $\log P$. The prognosis of reactivity for those compounds of interest lacking experimental information was carried out too.

\section{Experimental}

\subsection{Materials and Methods}

$\mathrm{HPR}$ and $\mathrm{H}_{2} \mathrm{O}_{2}$ concentrations assay. Concentrations of $\mathrm{HRP}^{2}(\mathrm{RZ}=2.7)$, ("Sigma", USA) and hydrogen peroxide ("Reakhim", Russia) were determined spectrophotometrically using $\varepsilon=102000 \mathrm{M}^{-1} \mathrm{~cm}^{-1}$ at $403 \mathrm{~nm}$ and $\varepsilon=72.4 \mathrm{M}^{-1} \mathrm{~cm}^{-1}$ at $230 \mathrm{~nm}$, respectively.

HRP activity assay. The peroxidase activity was determined at $293 \mathrm{~K}$ in $0.6 \mathrm{~cm}^{3} 0.01 \mathrm{M}$ phosphate buffer solutions ( $\mathrm{pH} 6.0$ ), with addition of both $0.8 \mathrm{~cm}^{3}$ enzyme solutions and of pyrogallol, and $0.6 \mathrm{~cm}^{3}$ of $2 \%$ aqueous solution of hydrogen peroxide. After $20 \mathrm{~s}$, the quantity of purpurogallin formed was determined using $\varepsilon=$ $=2470 \mathrm{M}^{-1} \mathrm{~cm}^{-1}$ at $\lambda=429 \mathrm{~nm}$ [13]. Amount of enzyme, enough for the formation of $1 \mathrm{mg}$ of purpurogallin in $20 \mathrm{~s}$ at pH 6.0 and $293 \mathrm{~K}$, was taken as a unit of peroxidase activity.

Phenols concentrations assay. The concentrations of phenol, $o-, m$-hydroxyphenols, $o-, m$-, $p$-chlorophenols, pentachlorophenol, $o-, m-, p$-cresols, $\alpha$-naphtol were measured using 4-aminoantipyrine method; of hydroquinone and 2,4,6-trichlorophenol - using their respective indices of molar absorbtivity, according to [14].

Kinetic studies. Kinetic measurements were conducted in $0.016 \mathrm{mM}$ Na-phosphate buffer solution $(\mathrm{pH}$ $7.0,298 \mathrm{~K}$ ) with phenols concentration $0.075-2.4 \mathrm{mM}$, hydrogen peroxide $-0.01-0.3 \mathrm{mM}$, HRP $-0.003 \mathrm{mM}$. The kinetic parameters $\left(V_{\max }, K_{m}\right)$ for corresponding phenols and $\mathrm{H}_{2} \mathrm{O}_{2}$ were determined using the Hanes linear transformation of the Michaelis-Menten equation [15].

QSPR analysis. 41 phenol derivatives (Fig. 2) were the subjects of the study. Such kinetic characteristics of HRP-catalyzed phenol derivatives oxidation reaction as its maximum rate $\left(V_{\max }\right)$ and reciprocal Michaelis constant $\left(K_{m}^{-1}\right)$ - index of phenols affinity for the enzyme - have been used as specific parameters of investigation. Compounds 1-13 form the training set and parameters 14-41 represent the prediction set. Boundary orbital energy calculations for the phenols were carried out by means of semi-empirical PM3 method (Hyperchem Software). Other molecule electronic structure descriptors were calculated with the use of Jolly-Perry (electronegativities equalization) method $[16,17]$.

\section{Results and Discussion}

Multiple linear regression (MLR) [18] equations have been obtained as a result of the conducted investigations:

For reciprocal Michaelis constant:

$$
K_{m}^{-1}=7.2+1.6 \log P-0.2 E N
$$

where $\log P$ - lipophilicity of molecule, EN electronegativity of molecule (additive). 
<smiles>Oc1ccccc1</smiles>

01<smiles>Oc1cccc(O)c1</smiles>

02<smiles>Oc1ccccc1O</smiles>

03<smiles>Oc1ccc(O)cc1</smiles>

04<smiles>Cc1cccc(O)c1</smiles>

10<smiles>Oc1ccccc1Cl</smiles>

05<smiles>Cc1ccc(O)cc1</smiles>

11<smiles>Oc1cccc(Cl)c1</smiles>

06<smiles>Oc1ccc(Cl)cc1</smiles><smiles>Cc1ccccc1O</smiles><smiles>COc1cccc(O)c1</smiles><smiles>COc1ccc(O)cc1</smiles><smiles>Oc1ccc(Cl)cc1Cl</smiles>

17<smiles>Oc1c(Cl)cc(Cl)cc1Cl</smiles>

12<smiles>Oc1cc(O)c2ccccc2c1</smiles>

18<smiles>Nc1ccc(O)cc1</smiles>

22<smiles>Nc1cccc(O)c1</smiles><smiles>Oc1ccc(Br)cc1Br</smiles>

25<smiles>Oc1c(Br)cc(Br)cc1Br</smiles>

26<smiles>Oc1cc(Cl)cc(Cl)c1</smiles>

27<smiles>O=C(O)c1ccc(O)cc1O</smiles>

33<smiles>Oc1cccc2c1Nc1c(O)cccc1O2</smiles>

39<smiles>O=[N+]([O-])c1ccccc1O</smiles>

28<smiles>O=C(O)c1cc(S(=O)(=O)O)ccc1O</smiles>

34
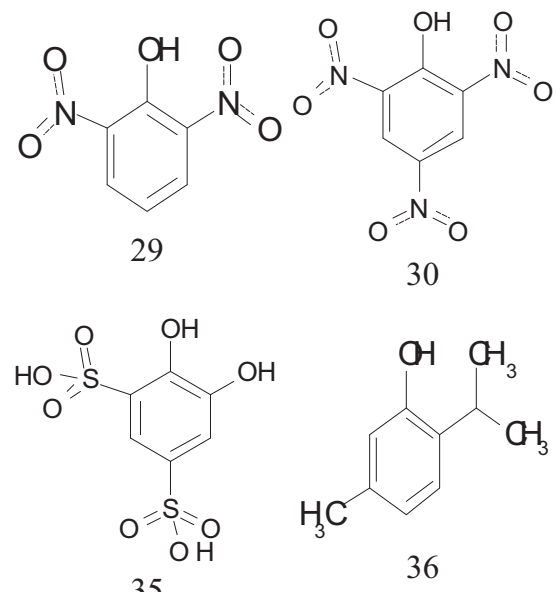

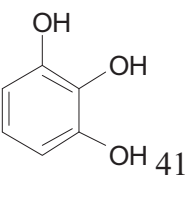

Fig. 2. Investigated compounds 
Statistical characteristics of the obtained model: determination coefficient $R^{2}=0.82$; cross validation determination coefficient $Q^{2}=0.74$ (the measure of predictive power of model); standard error of prediction $S E P=0.86$.

Contributions in investigated property change: $\log P-65 \%, E N-35 \%$.

For the rate constant:

$$
V_{\max }=-0.16+0.02 R_{f}-0.16 \log P
$$

where $R f$ - molecular refraction.

Statistical characteristics of the obtained model:

$$
R^{2}=0.80 ; Q^{2}=0.59 ; S E P=0.02 \text {. }
$$

Contributions in investigated property change:

$$
\log P-53 \%, R_{f}-47 \% \text {. }
$$

Although the mentioned regression models are significant, they have rather low predictive power $\left(Q^{2}<0.8\right)$.

Nowadays so-called "consensus" QSAR modeling becomes more and more popular [19]. It can be briefly described by the statement "More models that are good and different". The efficiency of this technique can be easily explained by the fact that nearly the same predictions obtained by different and independent methods (either statistical and descriptors generation) are more reliable than singular prediction made by even the best fitted and predictable model.

Therefore, to increase "structure-property" relationships adequacy we used PLS method, also known as projection to latent structures method [20], which was successfully applied for solving of a great number of QSAR/QSPR tasks, for example [21-26]. Quality of "structure-property" relationships obtained by this method is noticeably higher, than for MLR models.

The PLS regression model may be written as [20]:

$$
Y=b_{0}+\sum_{i=1}^{N} b_{i} x_{i}
$$

where $Y$ is an appropriate activity, $b_{i}$ is PLS regression coefficients, $X_{i}$ is an $i^{\text {th }}$ descriptor value, $N$ is a total amount of descriptors.

This is apparently not different from that of MLR, except that values of the coefficients $b$ are calculated using PLS. However, the assumptions underlying PLS are quite different from those of MLR. In PLS one assumes the $x$ variables to be collinear and PLS estimates the covariance structure in terms of a limited number of weights and loadings. In this way PLS can analyze any number of $x$-descriptors regarding to the number of molecules [20].

For reciprocal Michaelis constant the following PLS model has been obtained:

$$
\begin{gathered}
K_{m}^{-1}=22.5-80.2 q_{0}+0.0037 I_{z}+1.57 \mu-0.089 E N- \\
-0.99 I_{y} / I_{z}+15.8 I_{x} / I_{z}
\end{gathered}
$$

where $I_{x}, I_{p}, I_{Z}$-moments of inertia lengthways the coordinate axes, $\mu$ - dipole moment, $E N$ - total electronegativity of atoms, $q_{O}$ - phenolic oxygene atom partial charge.

Statistical characteristics of the obtained model: $R^{2}=0.92 ; Q^{2}=0.90 ; S E P=0.52 ;$ the number of structural descriptors in this model $N=6 K_{m}^{-1}$ predicted values for all compounds are shown in Table 1.

From the obtained results, it is possible to calculate the contributions of descriptors to the change of the investigated property: electronic structure characteristics $-66 \%$, form parameters $-34 \%$ (Fig. 3a).
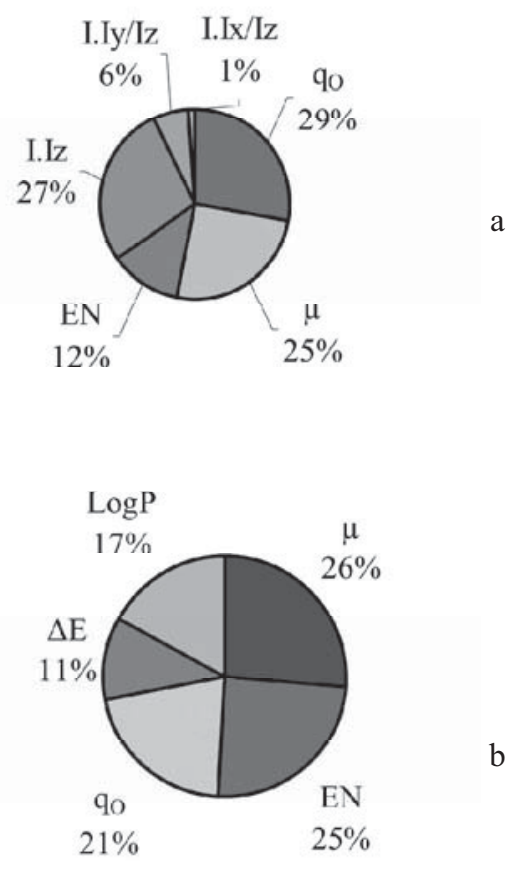

Fig. 3. Structural descriptors contributions in the change of $K_{m}^{-1}$ (a) and $V_{\max }$ (b); $I_{x}, I_{p}, I_{z}$-moments of inertia lengthways the coordinate axes, $\log P$ - lipophilicity, $\mu$ - dipole moment,

$E N$ - total electronegativity of atoms, $q_{\mathrm{O}}$ - phenolic oxygene atom partial charge, $\mathrm{D} E=E_{\text {Hомо }}-E_{L U M O}$

Substrates form influence, in all probability, is conditioned by the necessity for phenol molecules to correspond to enzyme cavity. Active molecules must be flat and moderately extended. The analysis of electronic parameters influence give the evidence that the greater negative charge on the phenolic oxygen atom the higher the reactivity of this compound. Apparently, this is related to donor properties of oxygen atom that determines more effective interaction between phenol and the iron ion during the enzymesubstrate complex formation. Moreover, as calculation results indicate, dipole moment of active molecules should not be large $(\mu<1 \mathrm{D})$. It is possible also to note that molecules with high total electronegativity of atoms have higher reactivity. This applies rightly both to PLS and MLR equations, in which this descriptor is included. 
It is possible to assume that in the given case this structural factor (high total electronegativity) defines higher stability of phenoxy-radicals which are formed in the oxidative enzymatic reaction.

For the rate constant the following PLS model has been obtained:

$$
\begin{gathered}
V_{\max }=-0.18-0.043 \mu+0.0047 E N-1.60 q_{0}- \\
-0.016 \log P-0.023 \Delta E
\end{gathered}
$$

where $\log P$ - lipophilicity, $\mu$-dipole moment, $E N$ - total electronegativity of atoms, $q_{\mathrm{O}}$ - phenolic oxygene atom partial charge, $\Delta E=E_{\text {Номо }}-E_{L U M O}$.

Statistical characteristics of the obtained PLS model for $V_{\text {max }}: R^{2}=0.91 ; Q^{2}=0.85 ; S E P=0.02 ; N=5$. $V_{\max }$ prediction values for all compounds are shown in Table 1.

Table 1

\begin{tabular}{|c|c|c|c|c|c|c|c|c|c|c|c|}
\hline Compound & $\begin{array}{c}K_{m}^{-1} \\
\text { obs/pred }\end{array}$ & $\begin{array}{c}V_{\max } \\
\text { obs/pred }\end{array}$ & $q_{O}$ & $\log P$ & $R f$ & $E N$ & $\Delta E$ & $\mu$ & $I_{Z}$ & $I_{X} / I_{Z}$ & $I_{Y} / I_{Z}$ \\
\hline 01 & $2.42 / 3.47$ & $0.04 / 0.04$ & -0.228 & 1.59 & 20.8 & 31.9 & 9.47 & 1.14 & 191 & 0 & 0.470 \\
\hline 02 & $3.03 / 3.33$ & $0.08 / 0.07$ & -0.229 & 1.21 & 22.5 & 35.4 & 9.33 & 1.12 & 276 & 0 & 0.489 \\
\hline 03 & $3.13 / 3.01$ & $0.08 / 0.06$ & -0.244 & 1.21 & 22.5 & 35.4 & 9.16 & 1.94 & 221 & 0 & 0.704 \\
\hline 04 & $2.65 / 2.09$ & $0.14 / 0.13$ & -0.228 & 1.21 & 22.5 & 35.4 & 8.92 & 0.00 & 337 & 0 & 0.272 \\
\hline 05 & $5.81 / 5.97$ & $0.00 / 0.00$ & -0.216 & 2.21 & 25.7 & 32.9 & 9.07 & 1.92 & 322 & 0 & 0.527 \\
\hline 06 & $6.41 / 5.90$ & $0.00 / 0.00$ & -0.224 & 2.21 & 25.7 & 32.9 & 9.25 & 1.94 & 417 & 0 & 0.352 \\
\hline 07 & $5.78 / 5.52$ & $0.00 / 0.03$ & -0.224 & 2.21 & 25.7 & 32.9 & 9.06 & 1.39 & 510 & 0 & 0.178 \\
\hline 08 & $2.62 / 3.27$ & $0.14 / 0.15$ & -0.247 & 2.5 & 33.1 & 50.0 & 7.94 & 1.89 & 644 & 0 & 0.405 \\
\hline 09 & $3.23 / 2.48$ & $0.07 / 0.08$ & -0.228 & 1.87 & 25.1 & 38.9 & 9.33 & 0.90 & 224 & 0.0070 & 0.700 \\
\hline 10 & $3.22 / 2.87$ & $0.07 / 0.08$ & -0.229 & 1.87 & 25.1 & 38.9 & 9.39 & 0.96 & 276 & 0.0057 & 0.493 \\
\hline 11 & $3.50 / 3.80$ & $0.08 / 0.07$ & -0.228 & 1.87 & 25.1 & 38.9 & 9.28 & 1.23 & 339 & 0.0046 & 0.271 \\
\hline 12 & $5.75 / 6.11$ & $0.04 / 0.02$ & -0.207 & 3.44 & 35.4 & 34.8 & 8.68 & 1.00 & 692 & 0 & 0.854 \\
\hline 13 & $8.13 / 7.84$ & $0.04 / 0.01$ & -0.205 & 4.68 & 45.2 & 36.7 & 8.35 & 1.10 & 1082 & 0 & 0.788 \\
\hline 14 & n.d./3.14 & n.d./0.10 & -0.237 & 1.55 & 26.8 & 42.3 & 9.09 & 1.59 & 342 & 0.0047 & 0.488 \\
\hline 15 & n.d. $/ 2.63$ & n.d./0.11 & -0.229 & 1.55 & 26.8 & 42.3 & 9.33 & 0.76 & 390 & 0.0041 & 0.449 \\
\hline 16 & n.d. $/ 2.79$ & n.d./0.14 & -0.228 & 1.55 & 26.8 & 42.3 & 8.93 & 0.36 & 506 & 0.0032 & 0.204 \\
\hline 17 & n.d./7.47 & n.d./-0.01 & -0.213 & 2.83 & 30.6 & 33.9 & 8.82 & 1.84 & 676 & 0 & 0.342 \\
\hline 18 & n.d./3.45 & n.d./0.14 & -0.231 & 2.5 & 33.1 & 50.0 & 8.02 & 1.34 & 613 & 0 & 0.510 \\
\hline 19 & n.d. $/ 2.43$ & n.d./0.10 & -0.229 & 1.5 & 26.8 & 42.3 & 9.29 & 1.22 & 279 & 0.0056 & 0.992 \\
\hline 20 & n.d./0.83 & n.d./0.14 & -0.228 & 0.84 & 24.1 & 38.8 & 9.51 & 0.00 & 277 & 0 & 1.000 \\
\hline 21 & n.d./4.54 & n.d./0.15 & -0.226 & 3 & 38.0 & 59.7 & 9.25 & 1.27 & 645 & 0.0861 & 0.267 \\
\hline 22 & n.d./1.01 & n.d./0.15 & -0.240 & 0.84 & 24.3 & 37.2 & 8.38 & 0.58 & 223 & 0 & 0.698 \\
\hline 23 & n.d./2.86 & n.d./0.10 & -0.232 & 0.84 & 24.3 & 37.2 & 8.74 & 1.11 & 275 & 0 & 0.495 \\
\hline 24 & n.d./5.01 & n.d./0.07 & -0.230 & 0.84 & 24.3 & 37.2 & 8.30 & 2.09 & 338 & 0 & 0.273 \\
\hline 25 & n.d./11.62 & n.d./-0.04 & -0.201 & 3.18 & 36.4 & 33.5 & 9.11 & 1.93 & 1436 & 0 & 0.208 \\
\hline 26 & n.d./10.28 & n.d./-0.02 & -0.191 & 3.98 & 44.1 & 34.2 & 8.77 & 1.02 & 1449 & 0 & 0.920 \\
\hline 27 & n.d. $/ 5.45$ & n.d./0.02 & -0.221 & 2.83 & 30.6 & 33.9 & 9.15 & 1.33 & 581 & 0 & 0.610 \\
\hline 28 & n.d./15.15 & n.d./-0.18 & -0.186 & 0.57 & 25.4 & 39.7 & 8.94 & 6.37 & 413 & 0 & 0.510 \\
\hline 29 & n.d./12.17 & n.d./-0.01 & -0.202 & -1.04 & 29.9 & 47.4 & 8.67 & 4.55 & 884 & 0 & 0.348 \\
\hline 30 & n.d./8.45 & n.d./0.13 & -0.186 & -2.65 & 34.4 & 55.1 & 8.94 & 1.89 & 997 & 0 & 0.924 \\
\hline 31 & $2.76 / 2.84$ & $0.07 / 0.10$ & -0.254 & 1.76 & 26.2 & 41.4 & 8.75 & 2.09 & 424 & 0 & 0.503 \\
\hline 32 & n.d./8.18 & n.d./0.01 & -0.220 & 1.16 & 26.2 & 41.4 & 9.10 & 3.04 & 650 & 0 & 0.198 \\
\hline 33 & n.d. $/ 2.02$ & n.d./0.17 & -0.256 & 1.38 & 27.9 & 44.8 & 8.78 & 1.20 & 656 & 0 & 0.329 \\
\hline 34 & n.d./7.97 & n.d./0.12 & -0.242 & 0.74 & 39.2 & 54.3 & 9.03 & 2.83 & 1317 & 0.0407 & 0.276 \\
\hline 35 & n.d./4.78 & n.d./0.27 & -0.274 & -0.22 & 48.3 & 61.2 & 8.55 & 1.92 & 1623 & 0.0655 & 0.408 \\
\hline 36 & n.d. $/ 4.55$ & n.d./0.15 & -0.226 & 3 & 38.0 & 59.7 & 9.25 & 1.27 & 644 & 0.0861 & 0.267 \\
\hline 37 & n.d./2.41 & n.d./0.15 & -0.253 & 1.51 & 32.7 & 52.7 & 9.17 & 2.18 & 519 & 0.0062 & 0.582 \\
\hline 38 & n.d. $/ 3.40$ & n.d./0.08 & -0.225 & 1.62 & 30.5 & 38.0 & 8.62 & 1.22 & 334 & 0 & 0.842 \\
\hline 39 & n.d./6.17 & n.d./0.18 & -0.232 & 2.1 & 42.4 & 63.8 & 8.04 & 2.16 & 1294 & 0.0010 & 0.350 \\
\hline 40 & n.d./32.28 & n.d./0.50 & -0.284 & 7.31 & 104.8 & 163.1 & 7.17 & 6.11 & 9792 & 0.0698 & 0.168 \\
\hline 41 & $2.30 / 3.13$ & $0.09 / 0.08$ & -0.245 & 0.84 & 24.1 & 38.8 & 9.23 & 2.19 & 281 & 0 & 0.766 \\
\hline
\end{tabular}

Observed and predicted values of investigated properties and values of descriptors of phenols

Notes: obs/pred - observed / predicted values of investigated properties; n.d. - no data, $I_{x}, I_{Y} I_{Z}$-moments of inertia lengthways the coordinate axes, $\log P$ - lipophilicity, $R f$ - molecular refraction, $\mu$ - dipole moment, $E N-$ total electronegativity of atoms, $q_{O}-$ phenolic oxygene atom partial charge, $\Delta E=E_{\text {номо }}-E_{L U M O}$ 


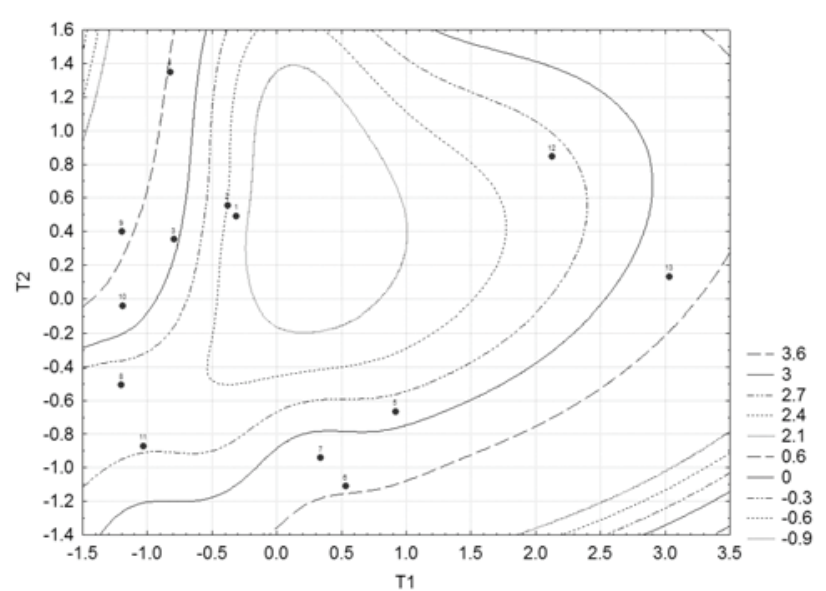

Fig. 4. $K_{m}^{-1}$ distribution of errors for QSPR model

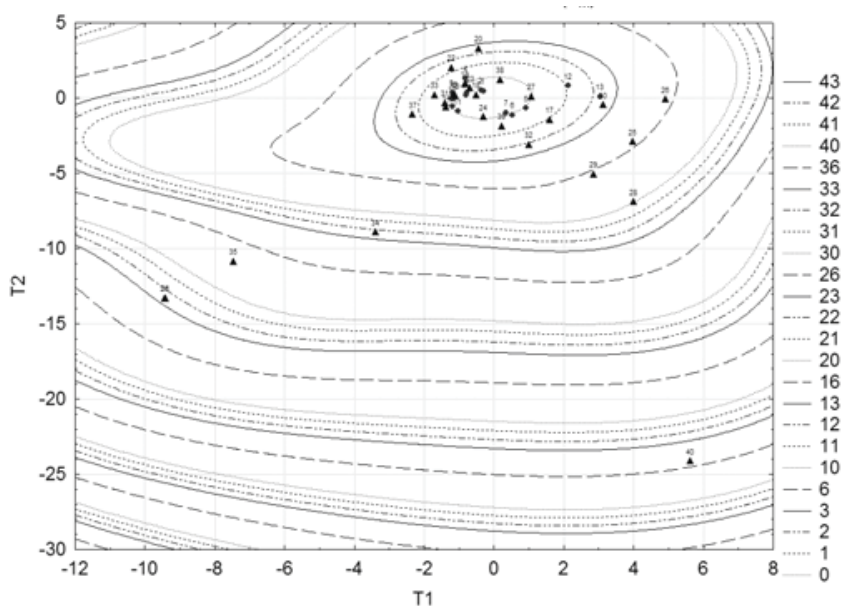

Fig. 6. $K_{m}^{-1}$ competence regions for QSPR model

The contributions of descriptors in the change of the investigated property are shown in the Fig. $4 \mathrm{~b}$. The same influence of lipophilicity on $V_{\max }$ value has been observed both in MLR and PLS models. Consequently, molecules with higher reactivity have relatively low lipophilicity $(\log P<1.6)$.

The analysis of electronic parameters influence (their total contribution equals $83 \%$ ) provides the evidence that, like in the $K_{m}^{-1}$ case, the greater negative charge of phenolic atom the higher the reactivity of this compound. Moreover, as the calculation results show, the dipole moment should not be large $(\mu<1 \mathrm{D})$, while the total electronegativity of atoms conversely must be increased. Furthermore, the decrease of difference between HOMO and LUMO energies $(\Delta E)$ enhances the degree of phenols conversion. Obviously, the polarizability of molecule increases in parallel with decreasing of $\Delta E$. This corresponds to the results of MLR model (2), where electronic polarizability (refraction), which increases the stability of the relevant phenoxy- radicals, makes a positive contribution too.

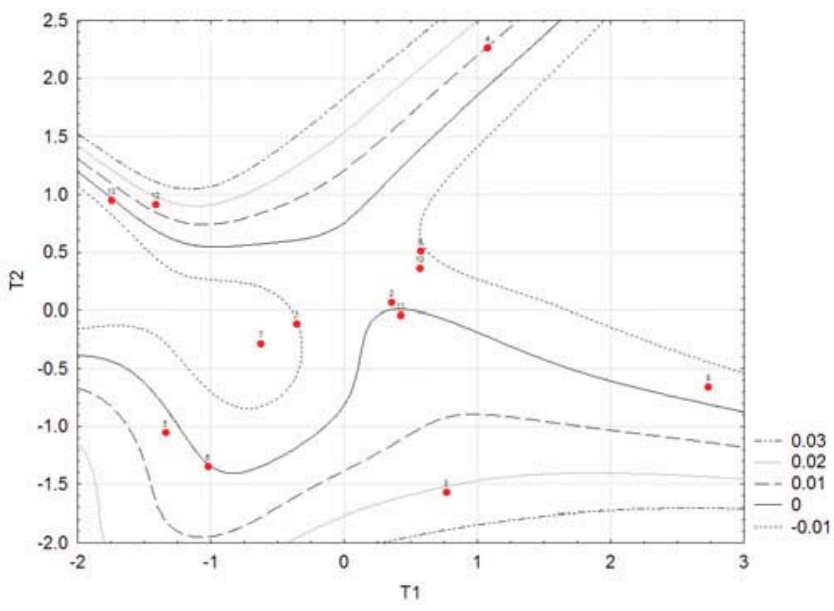

Fig. 5. $V_{\max }$ distribution of errors for QSPR model

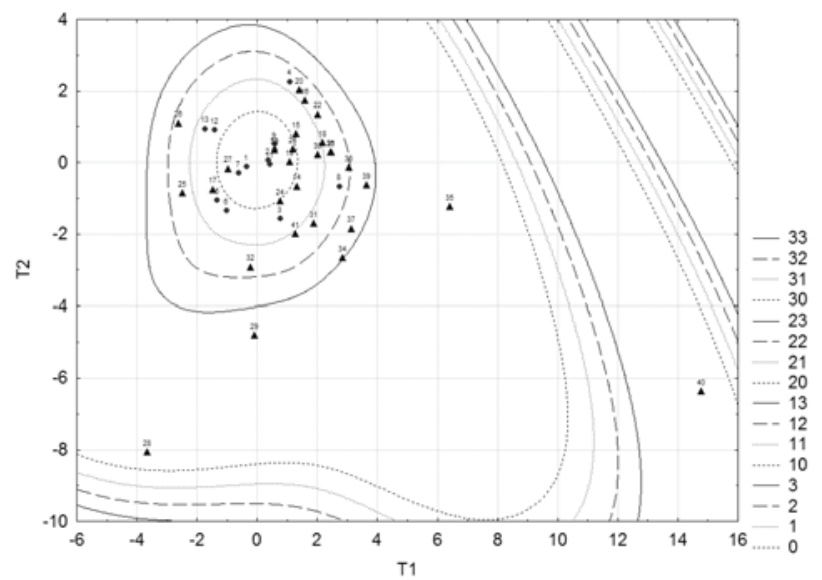

Fig. 7. $V_{\max }$ competence regions for QSPR model

Aimed to analyze PLS models predictive power, the "competence regions" (CR) have been examined. The distribution of errors (difference between predicted and experimental values of investigated property) in a space of latent variables T1-T2 calculated during the obtaining of PLS model is shown in Fig. 4 and 5.

From the analysis of these pictures, it is possible to determine the areas of structural signs space (SSS), where prognosis is most reliable. Obviously prognosis for the new molecules is more reliable, when they are located in the areas of SSS, which are close to similar areas of the training set molecules. Taking this into account, we have offered the procedure of CR estimation. It essentially consists in the following: the center of the training set molecules location in SSS $(\mathrm{T} 1=0 ; \mathrm{T} 2=0)$ has been determined. Further, the proper radius-vector length in relation to this center has been calculated for every molecule (including molecules from prediction set). After that, the average radius-vector $(R)$ and its standard deviation $(s)$ have been determined. Thus, all points that have the distance from the center less than $R+3 s$ fall in 
the CR model. As it can be seen from the Figs. 6 and 7 , the prognoses for molecules 28, 29, 35, and 40 are not very reliable in both models. Phenols 21, 25, 26, 29, 34, and 36 are falling out from the CR of $K_{m}^{-1}$ QSPR model. Evidently, the prognoses for the molecules that are close to center are most reliable.

The results of the prognosis for compounds 31 and 41 were checked by additional kinetic experiments with HRP for the obtained models quality control. As it is obvious from the Table 1, the correspondence of predicted and observed $V_{\max }$ and $K_{m}^{-1}$ values is quite satisfactory.

\section{Conclusions}

The structural descriptors for phenolic substrates, which determine their reactivity $\left(K_{m}^{-1}\right.$ and $\left.V_{\max }\right)$ in the peroxidase catalysis, were found.

PLS QSPR models obtained allow to predict the $K_{m}^{-1}$ and $V_{\max }$ values for the new phenolic substrates with sufficient reliability.

The analysis of models CR enables to estimate the prognosis reliability in every specific case.

\section{References}

[1] Veitch N. and Smith T.: Adv. Inorg. Chem., 2001, 51, 107.

[2] Krieg, R. and Halbhuber K.: Cell. Mol. Biol., 2003, 49, 547.

[3] Veitch N.: Phytochemistry, 2004, 65, 547.

[4] Davidova G., Yermacov O., Panasenko A. et al: Khimiya Rastitelnogo Syrja, 1998, 2, 15.

[5] Davidenko T., Sevastyanov O., Oseychuk O. and Brusilovsky Yu.: Dopovidi Nats. Akad. Nauk Ukrainy, 2004, 6, 154 .

[6] Davidenko T., Romanovskaya I., Oseychuk O. and Sevastyanov O.: Khimiya i Текhnologiya Wody, 2004, 26, 582.

[7] Davidenko T., Oseychuk O., Sevastyanov O. and Romanovskaya I.: Appl. Microb. Biotech., 2004, 40, 542.

[8] Guopsing Z. and Nicell J.: Water Res., 2000, 34, 1629.

[9] Wagner M. and Nicell J.: Water Res., 2002, 36, 4041.

[10] Koichi S. and Toichiro H.: J. Biol. Phys., 1991, 18, 175.

[11] Marjon J.and van Haandel I.: SBIC, 1996, 1, 460.

[12] Romanovskaya I., Muratov E., Kuz'min V. et al.: Dopovidi Nats. Akad. Nauk Ukrainy, 2006, 9, 161.
[13] Michlin D.: Biologicheskoye okislenie. Akad. Nauk SSSR, Moskwa 1956.

[14] Korenman I.: Photometricheskiy analiz. Khimiya, Moskwa 1975.

[15] Kornish-Bouden A.: Osnovy fermentativnoj kinetiki. Mir, Moskwa 1979.

[16] Jolly W. and Perry W.: J. Amer. Chem. Soc., 1973, 95, 5442.

[17] Kuz'min V. and Berestestkaya E.: Zh. Structurnoi Khimii, 1983, 24, 187.

[18] Ferster E., Rens B.: Methody correlyatsionnogo i regressionnogo analiza. Finansy i statistika, Moskwa 1983.

[19] Zhang S., Golbraikh A., Oloff S., Kohn H. and Tropsha A.: J. Chem. Inf. Model., 2006, 46, 1984.

[20] Rannar S., Lindgren F., Geladi P. and Wold S.: J. Chemometrics, 1994, 8, 111.

[21] Rodionova O. and Pomeransev A.: Chemometrica v analyticheskoy khimii. Finansy i statistika, Moskwa 2005.

[22] Cramer R., Patterson D. and Bunce J.: J. Am. Chem. Soc., 1988, 110, 5959.

[23] Klebe G., Abraham U. and Mietzner T.: J. Med. Chem. 1994, 37, 4130.

[24] Kuz'min V., Artemenko A., Lozitsky V. etal.: Acta. Biochim. Polon., 2002, 49, 157.

[25] Kuz'min V., Artemenko, A.G., Lozitskaya, R. et al.: SAR and QSAR in Env. Res., 2005, 16, 219.

[26] Kuz'min V., Artemenko A., Polischuk P. et al.: J. Mol. Mod., 2005, 11, 457.

\section{QSPR АНАЛІЗ РЕАКЦІЙНОÏ ЗДАТНОСТІ СУБСТРАТІВ ПЕРОКСИДАЗИ}

Анотація. Проведений QSPR аналіз реакиійной здатності похідних фенолу в реакиіях окиснення, щзо каталізуються ПОХ. За допомогою методів множинної лінійної регресії і PLS отримано статистичні моделі, що достатньо адекватно описують реакиійну здатність $\left(\kappa_{m}^{-1}\right.$, $\left.V_{\text {max }}\right)$ заміщених фенолів з використанням електронних параметрів молекул, їх ліпофільності, молекулярної рефракиіі і параметрів форми як структурних дескрипторів. Одержані моделі дозволяють з достатньою надійністю прогнозувати реакиійну здатність нових фенольних субстратів.

Ключові слова: QSPR аналіз, PLS, MLR, фенольні субстрати, пероксидаза хрону, комп ютерне прогнозування. 
